\title{
Seleksi Populasi Generasi Ke-2 (F2) Hasil Persilangan Pepaya Callina (IPB9) dan Carisya (IPB3)
}

\author{
The Selection of Second Generation (F2) of Papaya Population \\ Generated from Crossing between Callina (IPB9) and Carisya (IPB3)
}

\author{
Darda Efendi. ${ }^{12^{*}}$, Muhamad Rahmat Suhartanto ${ }^{1,2}$, Muhamad Syukur ${ }^{1,2}$, Sulassih ${ }^{1}$ \\ ${ }^{1}$ Pusat Kajian Hortikultura Tropika, LPPM IPB, Jl Raya Pajajaran Baranangsiang, Bogor 16144, Indonesia \\ ${ }^{2}$ Departemen Agronomi dan Hortikultura, Fakultas Pertanian IPB, Jl Meranti Darmaga, Bogor, Indonesia \\ *Penulis untuk korespondensi. email: dardaefendi@yahoo.com
}

Diterima 14 November 2016/Disetujui 9 Januari 2017

\begin{abstract}
Papaya (Carica papaya L.) is known as valuable fruit, because of it high nutrientcontent and economic value. Hybrid variety of papayaresultedfrom breeding program is still limited in Indonesia. The objective of this study is to describethe second generation of papaya population generated from crossing between Callina (IPB9) and Carisya (IPB3) to find a new genotype in the small size of fruit (500-700 g). Path analysis is used for weight, width, length, total soluble solution (TSS), flesh width, seed weight, total acidity, vitamin C, and weight of 100 dry seed. The fruit length, fruit width, flesh width, and seed weight showed positive correlation on fruit weight but total soluble solution (TSS) and seed weight had negative correlation. Fruit length give highest (0.64) direct effect on fruit weight then followed by fruit width (0.32) and seed weight (0.22). These characters can be used for selection trait on small size of papaya (500-750 g). The second generation population at Center for Tropical Horticulture Studies have the opportunity become a new variety.
\end{abstract}

Keywords: length, path analysis, weight, width

\section{ABSTRAK}

Pepaya (Carica papaya L.) merupakan salah satu komoditas buah tropis yang mempunyai nilai ekonomis dan diminati oleh konsumen karena pepaya memiliki kandungan gizi yang tinggi. Pepaya hibrida atau hasil persilangan belum banyak di Indonesia. Karakterisasi pada generasi ke-2 populasi pepaya hasil persilangan antara Callina (IPB9) dan Carisya (IPB3) perlu dikembangkan dalam program pemuliaan dengan tujuan untuk mendapatkan buah pepaya tipe kecil (500-700 g). Analisis sidik lintas digunakan untuk menganalisis bobot buah, diameter buah, panjang buah, total padatan terlarut (TSS), tebal daging buah, bobot biji, total asam, vitamin C, dan bobot 100 biji. Karakter diameter buah, panjang buah, dan tebal daging buah berkorelasi positif pada bobot buah, sedangkan total padatan terlarut (TSS) dan bobot biji berkorelasi negatif pada bobot buah. Karakter panjang buah memberikan nilai pengaruh langsung tertinggi (0.64) pada bobot buah, kemudian diameter buah (0.32) dan bobot biji (0.22). Ketiga karakter tersebut dapat digunakan sebagai karakter seleksi untuk buah pepaya tipe kecil (500-750 g). Populasi generasi ke-2 koleksi Pusat Kajian Hortikultura Tropika LPPM IPB berpotensi untuk dikembangkan menjadi varietas baru.

Kata kunci: bobot buah, diameter buah, panjang buah, sidik lintas

\section{PENDAHULUAN}

Pepaya (Carica papaya L) merupakan salah satu komoditas buah tropis mempunyai nilai ekonomis dan diminati oleh konsumen. Buah pepaya dapat dikonsumsi dalam bentuk segar maupun olahan, karena pepaya memiliki kandungan gizi yang tinggi seperti kalsium, magnesium, fosfor, zat besi, vitamin C, niacin, tiamin, riboflavin dan beta karoten (Nwofia dan Ojimelukwe, 2012). Produksi buah pepaya tampak terus mengalami peningkatan. Berdasarkan data Kementan (2014) produksi buah pepaya pada tahun
2009 mencapai 772,844 ton, kemudian pada tahun 2010 produksinya menurun menjadi 695,214 ton dan pada tahun 2011 produksi kembali meningkat menjadi 955,078 ton. Peningkatan produksi terjadi pada tahun 2012 mencapai 899,358 ton meskipun di tahun 2013 dan 2014 mengalami penurunan masing-masing hingga 871,275 ton dan 840,112 ton. Fluktuasi produksi pepaya masih merupakan kendala, menurut Sujiprihati dan Suketi (2009), kendala-kendala yang harus dihadapi diantaranya yaitu produktivitas yang rendah, ukuran buah yang tidak sesuai dengan keinginan konsumen, terbatasnya kultivar unggul yang berumur genjah 
dan berperawakan pendek serta kemampuan adaptasi yang rendah terhadap cekaman lingkungan (terutama kekeringan dan hama).

Varietas unggul pepaya masih terbatas jumlahnya. Beberapa varietas pepaya yang sudah dilepas oleh Menteri Pertanian sebagai buah unggulan nasional adalah Sari Gading, Sari Rona, Sukma, Carisya, Callina, Merah Delima, dan MJ-9 yang merupakan hasil seleksi populasi dan varietas Carindo merupakan hasil persilangan (Ditjen Horti 2012). Pepaya hasil persilangan koleksi Pusat Kajian Hortikultura Tropika LPPM IPB berpotensi untuk dikembangkan menjadi varietas pepaya unggul baru yang berdayasaing. Pepaya Callina memiliki keunggulan dalam hal rasa, aroma, warna daging buah, warna kulit buah, bentuk buah, kecepatan berbuah dan produktivitas yang tinggi, tetapi memiliki kelemahan yaitu kurang tahan terhadap penyakit busuk pangkal batangyang disebabkan oleh cendawan. Pepaya Carisya memiliki keunggulan berukuran kecil, manis, daging buah jingga kemerahan. Menurut Hafsah (2008) seleksi tanaman yang memiliki buah tipe kecil, berdaging buah tipis, total padatan terlarut tinggi dan buah yang keras dapat meningkatkan ketahanan terhadap penyakit antraknosa.

Analisis korelasi dan sidik lintas dapat digunakan untuk progam pemuliaan tanaman dalam menentukan karakter seleksi akibat pengaruh langsung dan tidak langsung terhadap karakter utama komponen hasil. Strategi untuk pengembangan karakter ideotipe untuk produksi dapat dilakukan terhadap karakter jumlah buah per tanaman, bobot buah, dan panjang buah karena komponen produksi pepaya berkorelasi positif dengan ronggabuah, jumlah buah per tanaman, bobot buah dan ketebalan daging buah (Jambhale et.al., 2014). Seleksi komponen hasil pada populasi pepaya generasi F2 hasil persilangan Callina (IPB9) dengan Carisya (IPB3) diharapkan dapat menghasilkan calon varietas baru tipe buah kecil (500-750 g), manis (minimal $10^{\circ}$ brix), berdaging merah jingga dan berbentuk lonjong.

\section{BAHAN DAN METODE}

Percobaan dilaksanakan pada populasi F2 yang sudah ditanam di Kebun Percobaan Pusat Kajian Hortikultura Tropika (PKHT) Pasir Kuda Ciomas Bogor sejak 7 Desember 2013. Jumlah tanaman yang digunakan adalah 120 tanaman yang terdiri dari 12 baris dan setiap baris terdiri dari 10 tanaman. Pengamatan dilakukan di Laboratorium Pascapanen PKHT IPB Baranangsiang Bogor. Bahan tanaman yang digunakan adalah generasi kedua (F2) hasil persilangan Pepaya Callina (IPB 9) sebagai tetua betina dan Carisya (IPB3) sebagai tetua jantan. Sampel yang diamati terdiri dari 9 baris dan setiap baris diambil 3 tanaman. Masing-masing tanaman diambil 3 buah untuk diamati. Pengamatan karakter buah yang digunakan yaitu bobot buah $(\mathrm{g})$, panjang buah $(\mathrm{cm})$, diameter buah $(\mathrm{cm})$, tebal daging buah $(\mathrm{cm})$, bobot biji dalam satu buah $(\mathrm{g})$, totalpadatan terlalut/TSS ( ${ }^{\circ}$ brix) menggunakan hand refractrometer merk ATAGO, totalasam tertitrasi (ATT) dititrasi dengan menggunakan larutan $\mathrm{NaOH} \quad 0.1 \mathrm{~N}$ dengan indikator
Phenolftalin $1 \%$, kadar vitamin C (asam askorbat) dilakukan menggunakan metode titrasi iodium $0.01 \mathrm{~N}$ dengan amilum $1 \%$, dan bobot 100 biji dalam kondisi kering. Analisis nilai koefisien korelasi linier sederhana dihitung berdasarkan rumus korelasi Pearson (Gomez dan Gomez, 2007) sebagai berikut:

$$
r=\frac{\sum x_{1} x_{2}}{\sqrt{\left(\sum x_{1}^{2}\right)\left(\sum x_{2}^{2}\right)}}
$$

Keterangan :

$\mathrm{r}=$ Koefisien korelasi; $\mathrm{x} 1$ dan $\mathrm{x} 2=$ Nilai tengah pada pengamatan peubah-peubah yang diamati

Keeratan hubungan antar karakter dianalisis menggunakan analisis korelasi Pearson dilanjutkan dengan analisis lintasan berdasarkan persamaan simultan sebagai berikut (Singh dan Chaudhary, 1979):

$\left[\begin{array}{cccc}r_{11} & r_{12} & \ldots & r_{1 p} \\ r_{21} & r_{22} & \ldots & r_{2 p} \\ \cdots & \cdots & \ldots & \cdots \\ \ldots & \ldots & \ldots & \cdots \\ r_{p 1} & \ldots & \cdots & r_{p p} \\ & \multicolumn{2}{c}{R_{x}} & \end{array}\right]\left[\begin{array}{c}C_{1} \\ C_{2} \\ \cdots \\ \ldots \\ C_{p} \\ C\end{array}\right]=\left[\begin{array}{c}r_{1 y} \\ r_{2 y} \\ \cdots \\ \ldots \\ r_{p y} \\ R_{y}\end{array}\right]$

Berdasarkan persamaan di atas, nilai $\mathrm{C}$ dapat dihitung menggunakan rumus:

$C=R_{x}^{-1} R_{y}$

Keterangan :

$\mathrm{Rx}=$ matriks korelasi antar peubah bebas

$\mathrm{Rx}-1=$ invers matriks $\mathrm{Rx}$

$\mathrm{C}=$ vektor koefisien lintasan yang menunjukkan pengaruh langsung setiap peubah bebas yang telah dibakukan terhadap peubah tak bebas

Ry = vektor koefisien korelasi antara peubah bebas xi (i $=1,2, \ldots . .11$ ) dengan peubah tak bebas y

\section{HASIL DAN PEMBAHASAN}

Populasi generasi F2 pepaya hasil persilangan Callina (IPB9) dan Carisya (IPB3) menunjukan keragaman dalam bentuk dan ukuran buah. Bentuk buah pada umumnya terbagi menjadi elliptic (menjorong), oblong (lonjong), elongated (memanjang), dan lengthened cylindrical (silindris) (IBPGR, 1988). Keragaan buah pepaya generasi F2 terdapat pada Gambar 1. Sujiprihati dan Suketi (2009) membagi ukuran buah pepaya menjadi tiga tipe yaitu besar (lebih dari 2500 g), sedang (750-2500 g), dan kecil (500-750 g). Rata-rata bobot buah hasil persilangan Callina dengan Carisya pada generasi ke-2 mencapai $975.30 \mathrm{~g}$, panjang buah $21.75 \mathrm{~cm}$, diameter $9.85 \mathrm{~cm}$, TSS $12.28^{\circ}$ brix, bobot biji $70.53 \mathrm{~g}$, TAT 2.11, vit C $118.22 \mathrm{mg} / 100 \mathrm{~g}$, bobot 100 biji $0.95 \mathrm{~g}$.

Pengembangan pemuliaan buah pepaya ditujukan untuk mendapatkan perbaikan karakter sesuai dengan ideotipe yang diharapkan oleh konsumen. Adapun ideotipe berdasarkan permintaan pasar modern maupun konsumen adalah sebagai berikut :(1) daging buah berwarna jingga, (2) manis, (3) kulit mulus, (4) bentuk lonjong, (5) bobot 0.8-1.5 kg (untuk tipe buah sedang), (6) tahan simpan, (7) bebas penyakit. Generasi populasi F2 hasil persilangan 

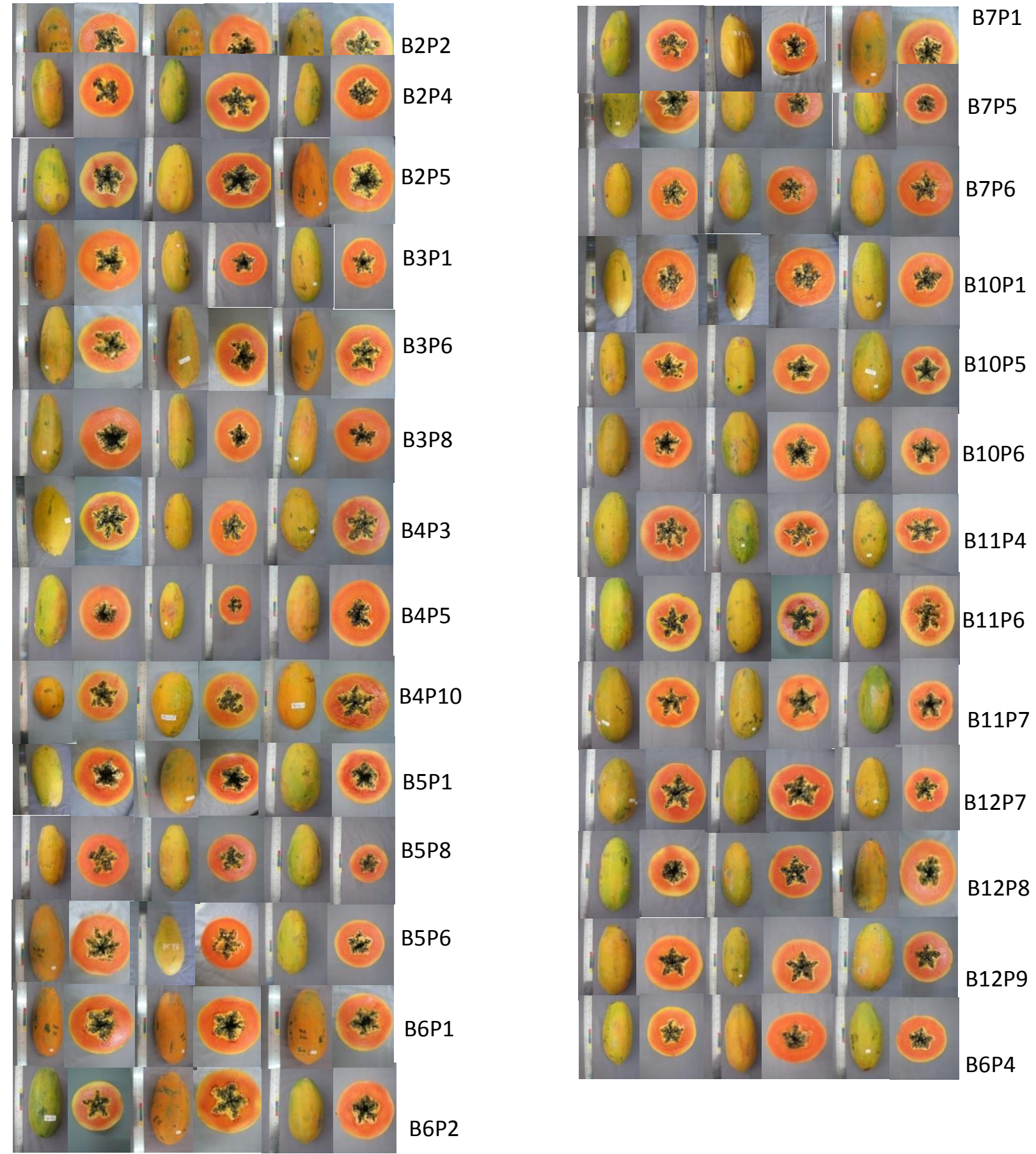

Gambar 1. Keragaan pepaya generasi F2 hasil persilangan Calina (IPB9) dengan Carisya (IPB3)

Callina dengan Carisya diharapkan memperoleh genotipe tanaman yang memiliki buah berukuran tipe kecil (500-750 g), manis dan daging buah berwarna merah jingga. Menurut Hafsah (2008) seleksi pada tanaman pepaya yang memiliki karakter berbuah kecil, berdaging buah tipis, total padatan terlarut tinggi dan buah yang keras dapat meningkatkan ketahanan terhadap penyakit antraknosa. Karakter panjang buah, tebal buah, persen padatan total terlarut, kekerasan buah, kematangan buah saat gejala pertama muncul, dapat digunakan sebagai karakter dalam menyeleksi pepaya terhadap ketahanan penyakit antraknosa pada genotipe
IPB1, IPB10, PB000174, Str-65 dan IPB 5. Berdasarkan hasil pengamatan 81 sampel tanaman generasi F2 belum mendapatkan genotipe tipe kecil (500-750 g). Rata-rata bobot buah yang diamati mencapai $975.30 \mathrm{~g}$ masih termasuk ke dalam tipe sedang (800-2500 g). Bobot terkecil berkisar $510 \mathrm{~g}$ dan bobot terbesar mencapai $1800 \mathrm{~g}$ seperti pada Tabel 1.

Seleksi karakter ideal pada suatu populasi dapat diawali dengan analisis korelasi untuk beberapa sampel (Meehl dan Waller, 2002). Seleksi melalui analisis korelasi dapat ditujukan untuk karakter jumlah buah per tanaman 
Tabel 1. Bobot buah, diameter, panjang, TSS, tebal daging, bobot biji basah, TAT, vitamin C dan bobot 100 biji pepaya populasi F2

\begin{tabular}{lrrr}
\hline \multirow{2}{*}{ Parameter } & & Penampilan \\
\cline { 2 - 4 } & Terkecil & Terbesar & Rata-rata \\
\hline Bobot $(\mathrm{g})$ & 510.00 & 1800.00 & 975.30 \\
Diameter (cm) & 7.00 & 19.50 & 9.85 \\
Panjang $(\mathrm{cm})$ & 28.00 & 8.00 & 21.75 \\
Total Soluble Solution & 10.30 & 14.80 & 12.28 \\
(0brix) & & & 2.88 \\
Tebal daging (cm) & 1.70 & 3.80 & 70.53 \\
Bobot biji basah (g) & 13.50 & 108.46 & 2.11 \\
Total Asam Tertitrasi & 0.87 & 3.83 & 118.22 \\
Vitamin C (mg/100g) & 59.56 & 175.75 & 0.95 \\
Bobot 100 biji (g) & 0.70 & 1.10 & \\
\hline
\end{tabular}

dan komponen hasil seperti pada buah delima (Meena et al., 2009) dan melon (Ibrahim dan Ramadan, 2013). Jambhale et.al (2014) menyatakan bahwa produksi pepaya berkorelasi positif dengan rongga buah, jumlah buah per tanaman, bobot buah, ketebalan daging buah, sehingga strategi untuk pengembangan karakter ideotipe untuk produksi dapat dilakukan terhadap karakter jumlah buah per tanaman, bobot buah dan panjang buah. Heritabilitas yang tinggi terdapat pada karakter bobot biji setiap buah, rasio bobot daging buah terhadap biji, produktivitas setiap tanaman, panjang buah, jarak buku pertama pada batang dari permukaan tanah, jumlah buah per tanaman, rongga buah, diameter buah dan bobot buah sangat efektif untuk dijadikan sebagai karakter seleksi dalam pengembangan pemuliaan tanaman pepaya.

Karakter bobot buah dapat dijadikan sebagai karakter seleksi terhadap komponen hasil seperti pada buah mangga (Majumder et al., 2012) dan nenas (Nasution, 2010). Karakter tipe buah kecil dapat dijadikan sebagai komponen hasil berdasarkan parameter bobot buah. Hubungan karakter bobot buah terhadap karakter panjang, diameter, bobot biji basah, TSS, TAT, Vitamin C dan bobot biji 100 butir pada populasi generasi $\mathrm{F} 2$ pepaya hasil persilangan Callina dengan Carisya terdapat pada Tabel 2.

Berdasarkan Tabel 2 karakter diameter buah (0.28), panjang buah (0.67), tebal buah (0.41) dan bobot biji (0.63) berkorelasi positif terhadap bobot buah. Bobot buah yang semakin besar akan memiliki diameter, panjang, tebal, dan bobot biji yang besar. Total padatan terlarut (-0.25) dan kandungan vitamin $\mathrm{C}(-0.28)$ berkorelasi negatif terhadap bobot buah, sehingga kedua karakter tersebut dapat menjelaskan semakin kecil bobot buah berkecenderungan memiliki total padatan terlarut dan vitamin $\mathrm{C}$ yang tinggi. Koefisien korelasi yang signifikan diantara dua karakter belum tentu mengindikasikan bahwa kedua karakter tersebut memiliki hubungan satu dengan yang lainnya (Majumder et al. 2012) dan berapa besar hubungan tersebut (Meehl

Tabel 2. Korelasi karakter bobot buah terhadap diameter, panjang, total padatan terlarut (TSS), tebal daging, bobot biji, total asam tertitrasi, vitamin $\mathrm{C}$, bobot 100 biji

\begin{tabular}{llllllllll}
\hline Karakter & DM & PJG & TSS & TBL & BJ & TAT & VIT C & $100 B J$ & BOT \\
\hline DM & & $-0.274^{*}$ & $-0.296^{* *}$ & $0.223^{*}$ & $0.298^{* *}$ & 0.181 & $-0.332^{* *}$ & 0.074 & $0.281^{*}$ \\
PJG & $-0.274^{*}$ & & -0.050 & $0.235^{*}$ & $0.381^{* *}$ & 0.054 & -0.033 & 0.099 & $0.676^{* *}$ \\
TSS & $-0.296^{* *}$ & -0.05 & & -0.117 & $-0.344^{* *}$ & -0.032 & 0.212 & -0.052 & $-0.250^{*}$ \\
TBL & $0.223^{*}$ & $0.235^{*}$ & -0.117 & & $0.304 * *$ & 0.03 & -0.065 & 0.049 & $0.416^{* *}$ \\
BJ & $0.298^{* *}$ & $0.381^{* *}$ & $-0.344^{* *}$ & $0.304 * *$ & & $0.292^{* *}$ & -0.172 & 0.179 & $0.631^{* *}$ \\
TAT & 0.181 & 0.054 & -0.032 & 0.03 & $0.292^{* *}$ & & $-0.124 *$ & 0.029 & 0.171 \\
VIT C & $-0.332^{* *}$ & -0.033 & 0.212 & -0.065 & -0.172 & -0.124 & & -0.025 & $-0.289 * *$ \\
100BJ & 0.074 & 0.099 & -0.052 & 0.049 & 0.179 & 0.029 & -0.025 & 0.207 \\
BOT & $0.281 *$ & $0.676^{* *}$ & $-0.250^{*}$ & $0.416^{* *}$ & $0.631 * *$ & 0.171 & $-0.289 * *$ & 0.207 & \\
\hline
\end{tabular}

Keterangan : $\mathrm{DM}=$ diameter buah, $\mathrm{PJG}=$ panjang buah, $\mathrm{TSS}=$ total padatan terlarut, $\mathrm{TBL}=$ tebal daging buah, $\mathrm{BJ}=$ bobot biji, $\mathrm{TAT}=$ total asam tertitrasi, VIT C $=$ vitamin $\mathrm{C}, 100 \mathrm{BJ}=$ bobot $100 \mathrm{biji}$, BOT $=$ bobot buah. $*$ berbeda nyata pada taraf alpha $5 \%$ dan ** berbeda sangat nyata pada taraf alpha $1 \%$ 
dan Waller, 2002), sehingga perlu dilakukan analisis sidik lintas untuk menjelaskan hubungan sebab akibat dan tingkat keeratan antar karakter. Koefisien analisis sidik lintas merupakan standar regesi yang sederhana dengan membagi koefisien korelasi untuk menentukan pengaruh langsung dan tidak langsung (Majumder et al. 2012). Karakter diameter buah, tebal daging buah dan total asam mempunyai pengaruh langsung positif terhadap bobot buah melalui analisis sidik lintas (Nasution, 2010). Hubungan pengaruh langsung dan tidak langsung terhadap tipe buah/bobot buah pada populasi generasi F2 pepaya hasil persilangan Callina dengan Carisya terdapat pada Tabel 3.

Berdasarkan Tabel 3 karakter yang memberikan pengaruh langsung terhadap bobot buah dengan nilai tertinggi adalah panjang buah (0.64), diameter (0.32), dan bobot biji (0.22), sehingga karakter panjang buah dapat dijadikan sebagai karakter seleksi untuk mendapatkan buah berukuran kecil (500-750 g). Semakin pendek ukuran buah maka semakin kecil ukuran buah, sebaliknya semakin panjang buah maka semakin besar buah (Gambar 2).

Total padatan terlarut menunjukan pengaruh langsung bernilai negatif terhadap bobot buah. Semakin kecil bobot buah maka buah semakin manis, dan berlaku sebaliknya semakin besar bobot buah diduga rasa manis semakin berkurang. Vitamin $\mathrm{C}$ pada karakter utama memberikan pengaruh langsung bernilai negatif terhadap bobot buah, sehingga semakin kecil bobot buah maka semakin tinggi kandungan vitamin $\mathrm{C}$ dan semakin besar bobot buah mengandung vitamin $\mathrm{C}$ yang lebih rendah. Berdasarkan penelitian Nwofia dan Ojimelukwe (2012) karakter vitamin $\mathrm{C}$ tidak dapat digunakan sebagi karakter seleksi meskipun menunjukan berbeda nyata. Berdasarkan analisis sidik lintas diperoleh tujuh calon genotipe tipe pepaya ukuran kecil untuk dilanjutkan ke generasi F3 (Tabel 4).

Genotipe yang terpilih memiliki kisaran bobot buah 660-950 g dengan bentuk buah oblong, obovate dan bulat (Gambar 3). Berdasarkan data dari 81 genotipe yang diamati diperoleh bobot terendah adalah $510 \mathrm{~g}$, tetapi

Tabel 3. Pengaruh langsung dan tidak langsung karakter yang diamati terhadap bobot per buah

\begin{tabular}{|c|c|c|c|c|c|c|c|c|c|}
\hline \multirow[b]{2}{*}{ Karakter } & \multirow{2}{*}{$\begin{array}{c}\text { Pengaruh } \\
\text { langsung C) }\end{array}$} & \multicolumn{8}{|c|}{ Pengaruh tidak langsung } \\
\hline & & DM & PJG & TSS & TBL & BJ & TAT & VIT C & $\begin{array}{c}\text { Jumlah } \\
\text { total }\end{array}$ \\
\hline Diameter & 0.322 & & 0.643 & 0.002 & 0.026 & 0.066 & 0.037 & 0.005 & 0.779 \\
\hline Panjang & 0.643 & -0.088 & & 0.000 & 0.027 & 0.084 & 0.004 & 0.007 & 0.034 \\
\hline TSS & -0.005 & -0.095 & -0.191 & & -0.013 & -0.076 & -0.024 & -0.004 & -0.403 \\
\hline Tebal daging & 0.114 & 0.072 & 0.144 & 0.001 & & 0.067 & 0.007 & 0.004 & 0.295 \\
\hline Bobot biji & 0.221 & 0.096 & 0.192 & 0.002 & 0.035 & & 0.019 & 0.013 & 0.357 \\
\hline Vitamin C & -0.113 & -0.107 & -0.214 & -0.001 & -0.008 & -0.038 & & -0.002 & -0.369 \\
\hline Bobot 100 biji & 0.072 & 0.024 & 0.048 & 0.000 & 0.006 & 0.040 & 0.003 & & 0.120 \\
\hline Total C & 1.253 & & & & & & & & \\
\hline Residu & 0.488 & & & & & & & & \\
\hline
\end{tabular}

Keterangan: $\mathrm{DM}=$ diameter buah, $\mathrm{PJG}=$ panjang buah, $\mathrm{TSS}=$ total padatan terlarut, $\mathrm{TBL}=$ tebal daging buah, $\mathrm{BJ}=$ bobot biji, $\mathrm{TAT}=$ total asam tertitrasi, VIT C $=$ vitamin $\mathrm{C}, 100 \mathrm{BJ}=$ bobot $100 \mathrm{biji}$
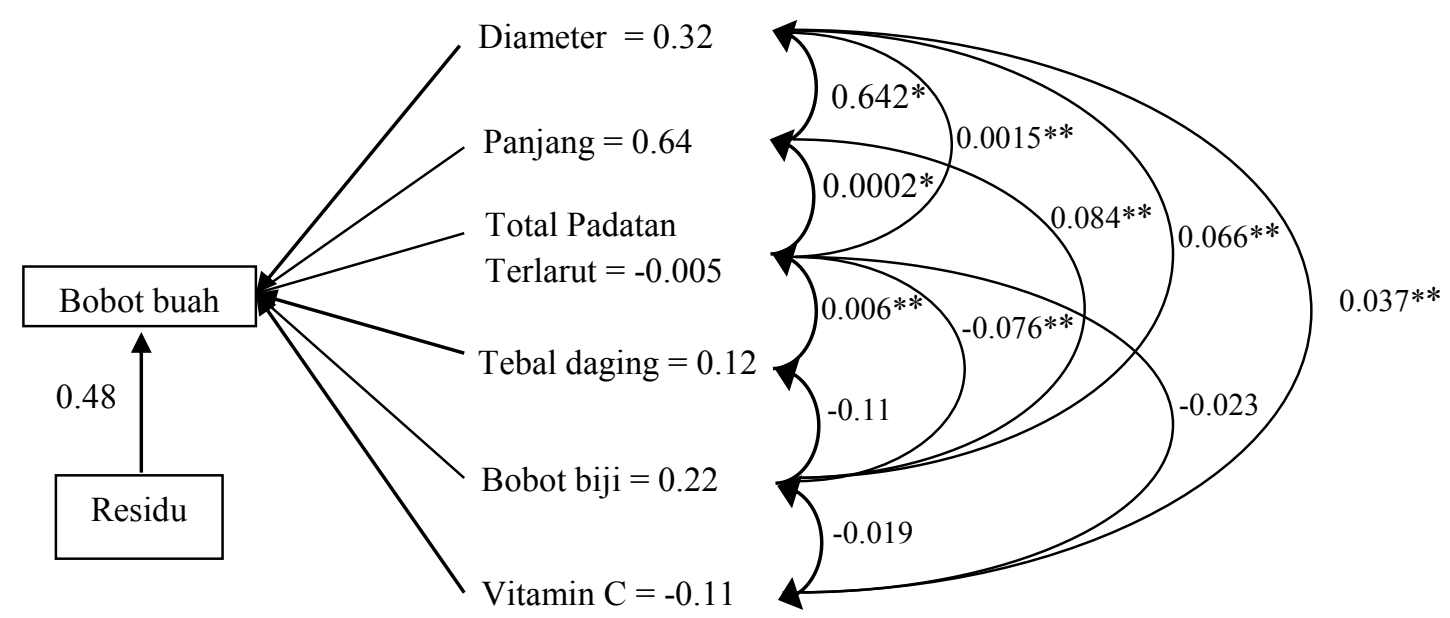

Gambar 2. Analisis sidik lintas bobot buah pepaya terhadap karakter diameter, panjang, total padatan terlarut, tebal daging, bobot biji dan vitamin C 
dari penampilan bentuk buah kurang menarik, sehingga pemilihan genotipe ditujukan untuk 7 buah yang mewakili dari bobot, bentuk buah, TSS dan ketebalan daging buah, dengan harapan pada populasi F3 dapat diperoleh genotipe yang diharapkan untuk meningkatkan karakter Callina dan Carisya.

Tabel 4. Calon genotipe terpilih untuk populasi generasi F3

\begin{tabular}{lccccccccc}
\hline Genotipe & $\begin{array}{c}\text { Diameter } \\
(\mathrm{cm})\end{array}$ & $\begin{array}{c}\text { Panjang } \\
(\mathrm{cm})\end{array}$ & $\begin{array}{c}\text { TSS } \\
\left({ }^{\circ} \text { brix }\right)\end{array}$ & $\begin{array}{c}\text { Tebal } \\
\text { daging } \\
\text { buah }(\mathrm{cm})\end{array}$ & $\begin{array}{c}\text { Bobot biji } \\
\text { basah }(\mathrm{g})\end{array}$ & TAT & $\begin{array}{c}\text { Vit C } \\
(\mathrm{mg} /\end{array}$ & $\begin{array}{c}\text { Bobot biji } \\
100 \text { butir }\end{array}$ & $\begin{array}{c}\text { Bobot } \\
\text { buah }\end{array}$ \\
\hline B7P1c & 9.20 & 21.00 & 13.50 & 2.70 & 63.87 & 1.75 & 146.61 & 0.90 & 890.00 \\
B4P10b & 10.00 & 17.00 & 14.00 & 3.00 & 40.69 & 1.43 & 114.75 & 1.00 & 660.00 \\
B4P10a & 10.20 & 18.00 & 14.50 & 3.00 & 48.43 & 2.79 & 157.01 & 1.00 & 680.00 \\
B10P1c & 8.00 & 20.00 & 14.80 & 3.00 & 54.89 & 1.92 & 184.25 & 0.90 & 680.00 \\
B7P5c & 9.00 & 20.00 & 11.60 & 2.60 & 55.84 & 1.35 & 208.63 & 1.00 & 820.00 \\
B12P9c & 9.20 & 20.00 & 11.90 & 2.80 & 69.60 & 2.31 & 119.55 & 1.00 & 850.00 \\
B10P5c & 9.50 & 24.00 & 12.20 & 2.80 & 60.23 & 2.39 & 119.56 & 1.10 & 950.00 \\
B12P9a & 9.70 & 20.50 & 14.00 & 2.60 & 57.47 & 1.74 & 145.52 & 1.10 & 920.00 \\
\hline
\end{tabular}
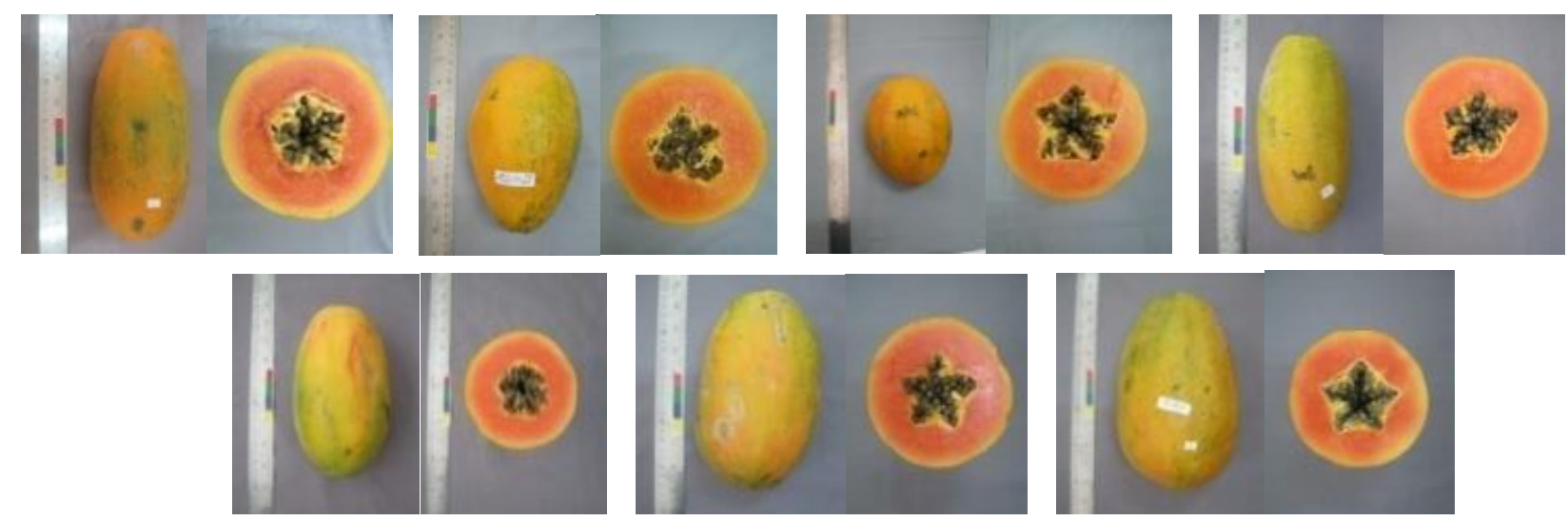

Gambar 3. Calon genotipe terpilih untuk dilanjutkan ke generasi F3

\section{KESIMPULAN}

Analisis sidik lintas dapat menunjukan karakter panjang dan diameter buah sebagai karakter seleksi untuk mendapatkan calon varietas baru yaitu dengan karakter ideal pada bobot buah pepaya tipe kecil yang memiliki rasa manis dan kandungan vitamin $\mathrm{C}$ yang tinggi. Genotipe B7P1c, B4P10b, B4P1a, B10P1c dan B7P5c terpilih sebagai calon kandidat pepaya tipe kecil meskipun rata-rata bobot yang dihasilkan mencapai 600-800 g.

\section{UCAPAN TERIMA KASIH}

Ucapan terimakasih disampaikan kepada Sistem Informasi Manajemen Penelitian dan Pengabdian Kepada Masyarakat, Kementerian Riset dan Teknologi Pendidikan Tinggi yang memfasilitasi pendanaan penelitian Strategi Nasional.

\section{DAFTAR PUSTAKA}

[DITJEN HORTI] Direktorat Jenderal Hortikultura. 2012. Daftar varietas hortikultura. Direktorat Perbenihan Hortikultura, Direktorat Jenderal Hortikultura, Kementerian Pertanian. Jakarta.

[KEMENTAN] Kementrian Pertanian. 2014. Data produksi nasional. Kementerian Pertanian. http://www. pertanian.go.id [29 September 2015].

Gomez, K.A., A.A. Gomez. Penerjemah : Sjamsuddin E., dan Justika S. Baharsjah, 2007. Prosedur statistik untuk penelitian pertanian. Edisi ke-2. Universitas Indonesia. Jakarta.

Hafsah, S. 2008. Uji korelasi dan sidik lintas beberapa karakter pepaya terhadap ketahanan antraknosa. Agista 1:225-230. 
Ibrahim, E.A., A.Y. Ramadan. 2013. Correlation and path coefficient analyses in sweet melon (Cucumis melo var. Aegypticus L.) under irrigated and drought conditions. Pakistan Journal of Biological Sciences 16 (3):610-616.

[IBPGR] International Board for Plant Genetic Resources. 1988. Descriptors for Papaya. International Board for Plant Genetic Resources. Rome.

Jambhale, V.M., N.S. Kute, S.V. Pawar. 2014. Studies on genetic variability parameters, character association and path analysis among yield and yield contributing traits in papaya (Carica papaya L.). The Bioscan 9(4):1711-1715.

Majumder, D.A.N., L. Hassan, M.A. Rahim, M.A. Kabir. 2012. Correlation and path coefficient analysis of mango (Mangifera indica L.). Bangladesh J. Agil. Res. 37(3):493-503

Meehl, P.E., Niels G. Waller. 2002. The path analysis controversy: A new statistical approach to strong appraisal of verisimilitude. American Psychological Association, Inc.7 (3):283-300.
Meena, K.K., R. Singh, S. Pareek, S.K. Singh, P. Kashyap. 2009. Studies on correlation coefficient and path analysis in pomegranate for morphological and yield characters. Indian J. Hort. 66(4):516-519.

Nasution, M.A. 2010. Analisis korelasi dan sidik lintas antara karakter morfologi dan komponen buah tanaman nenas (Ananas comosus L. Merr.). Crop Ago 3 (1).

Nwofia, G.E., P. Ojimelukwe. 2012. Variability in proximate, mineral and vitmin contens of Carica papaya (L.) leaves, fruit pulp and seeds. Int. J. Med. Arom. Plants 2(1):90-96.

Singh, R.K., B.D. Chaudhary. 1979. Biometrical methods in quantitative genetic analysis. Kalyana Publishers. Ludhiana. New Delhi.

Sujiprihati, S., K. Suketi. 2014. Budidaya Pepaya Unggul. Penebar Swadaya. Jakarta. 